\title{
Work-Family Conflict, Organizational Commitment, and Burnout Among Food and Beverages Industries
}

\author{
Tiara Carina \\ Faculty of Economics and Business, Udayana University, PB Sudirman Street, Denpasar, Bali, Indonesia \\ Wayan Gede Supartha \\ Faculty of Economics and Business, Udayana University, PB Sudirman Street, Denpasar, Bali, Indonesia
}

\begin{abstract}
Burnout is a problem encountered by employees in food and beverages industry in Kuta, Bali. According to Job Demand-Resources (JD-R) Model, burnout arises due to the work-family conflict. Although there is a significant relationship between work-family conflict and burnout, there is previous study that state individual is able to maintain their psychological wellbeing despite experiencing work-family conflict. The potential moderator in the relationship is organizational commitment. The sample was 196 employees from five food and beverages companies in Kuta, Bali which are registered in the Department of Human and Energy Resources of Bali Province. Data were collected through Burnout Instrument $(r=0.725)$, Organizational Commitment Instrument $(r=0.805)$, and Work-Family Conflict Instrument $(\mathrm{r}=0.934)$. Data was analyzed using Moderated Regression Analysis (MRA). The results were work-family conflict significantly affected burnout (sig. B1 $=0.000 ; \beta 1=2.391)$ and organizational commitment significantly weakened the effect of work-family conflict on burnout (sig. B3=0.035; $\beta 1=2.391 ; \beta 3=-0.876$ ). Organizational commitment is a quasi-moderator in this study (sig. B3 = 0.035; sig. B2 $=0.034$ ). Based on the results, company is able to create flexible work environment to reduce work-family conflict and designs training to increase organizational commitment in order to prevent burnout.
\end{abstract}

Keywords: Work-Family Conflict, Organizational Commitment, Burnout, Food and Beverages

DOI: $10.7176 / \mathrm{EJBM} / 11-21-06$

Publication date:July $31^{\text {st }} 2019$

\section{Introduction}

Bali is a tourist destination known throughout the world for its natural and cultural beauty. In 2014, Bali tourism sector grew above the national average, with a growth rate of $6.86 \%$ which was higher than the national economic growth percentage of 5.21\% (Wijaya, 2015). It has triggered investors to build related businesses, such as hotels and restaurants. According to the Bali Provincial Statistics Agency (2018), Badung is the district with the largest number of restaurants in Bali, which is 823 out of a total of 2251 restaurants. More specifically, 560 of the 823 restaurants in Badung are in Kuta District.

According to preliminary study, the company has difficulty in handling employees who have characteristics not having enthusiasm at work, often pretending to be sick, and not serving customers wholeheartedly, which is similar to the characteristics of burnout. Burnout is a phenomenon that has the potential to occur in employees who work in high-pressure workplaces (Smith, et al., 2018). Problems regarding burnout must be addressed so as not to cause negative impacts on individuals and companies. Individuals with burnout will experience a decrease in productivity and a higher level of absenteeism, experience symptoms of depression (Ahola, et al., 2017), and decreased motivation and performance (Hill \& Curran, 2015). Based on Job Demand-Resources (JD-R) Model, burnout arises because of an imbalance between job demands and job resources. One of the job demands referred to in this model is role conflict (Wu, et al., 2019). The role conflict often experienced by employees is work-family conflict. Work-family conflict is defined as the inconsistency between work and personal life (Pu, et al., 2016).

Although there is a significant relationship between work-family conflict and burnout (Chen, et al., 2018; Adam, et al., 2008; Lingard \& Francis, 2006), in previous studies there were employees who maintained their psychological health despite work-family conflict (Westman, et al., 2008). This research gap made researchers want to explore the moderator variables that can strengthen or weaken work-family conflict and burnout relationships. The potential moderator in work-family conflict and burnout relationships is organizational commitment. Organizational commitment can be categorized as job resources in the JD-R model. Organizational commitment is defined as the psychological attachment of individuals to organizations, which can also refer to the desire to remain in the organization (Allen \& Meyer, 1993). According to the JD-R model, organizational commitment functions in achieving work goals, reducing work-related physiological and psychological costs so as to reduce the likelihood of burnout (Demerouti, et al., 2001). This is supported by previous research which states that organizational commitment significantly affects burnout (Lee, et al., 2016). Research conducted by Galletta, et al. (2019) showed that there was a moderating effect of collective affective commitment on the effect of workfamily conflict on burnout. Based on this, the researchers wanted to find out how the influence of work-family conflict on burnout moderated by organizational commitment in food and beverages industry in Kuta, Bali. 


\section{Literature Survey}

\subsection{Burnout}

Burnout is defined as a psychological syndrome of fatigue, a feeling of cynicism and loss of attachment to work, as well as a sense of ineffectiveness and lack of achievement, in response to chronic stress on the job. Burnout is associated with poor health outcomes such as poor health behavior, somatic health and mental health, and organizational outcomes such as long-term sick leave, poor performance, and low cognitive function, so it is important to prevent burnout in employees (Nilsen, et al., 2016). Dunham considers burnout as an extreme form of work-related stress and considers burnout as a product of an irreconcilable stress response (Yu, et al., 2015). Maslach and Jackson developed the Maslach Burnout Inventory (MBI) by categorizing burnout into three dimensions namely emotional fatigue, depersonalization, and reduced personal achievement. Emotional fatigue is interpreted as emotional depletion due to excessive psychological and physiological demands. Depersonalization refers to the treatment of others as objects rather than people because of cynical attitudes and negative feelings. Reduced personal attainment represents a tendency towards negative judgment and dissatisfaction with people because of their unmet performance or responsibilities.

\subsection{Work-Family Conflict}

Work-family conflict is defined as the inconsistency between work and personal life. Work-family conflict can make individuals ignore personal responsibility due to job demands, and vice versa (Pu, et al., 2016). Greenhaus and Beutell define work-family conflict as a form of conflict control in which the role pressures of the work and family environment are mutually incompatible (Carlson, et al., 2000). Work-family conflict consists of 3 dimensions, namely time, strain, and behavioral. According to Greenhaus \& Beutel (1985), time-based conflict occurs when time spent on one role impedes participation in another role. Strain-based conflict occurs whenever tensions caused by one role affect the performance of other roles. Behavioral-based conflict occurs at any time when the pattern of individual's behavior is not in line with expectations.

The assumption of the JD-R model is that the psychosocial work environment can be categorized into two groups, namely job resources and job demands. According to the JD-R model, the condition of individuals most vulnerable to strains is when they lack of job resources or feel overwhelmed by job demands. When job demands exceed job resources, strains increase over time and individuals tend to experience burnout (Demerouti, et al., 2001). In this study, work-family conflict is one of the job demands on the JD-R model. Work-family conflict results in difficulties in fulfilling employee obligations in the workplace, resulting in the appearance of burnout due to the presence of high stressors.

H1: Work-family conflict positively influences burnout.

\subsection{Organizational Commitment}

Hall, et al. (1970) defines organizational commitment as a process where the goals of the organization and its members become increasingly integrated and congruent. Sheldon defines organizational commitment as an attitude or orientation towards the organization, which connects or attracts individual identity to the organization (in Karim \& Noor, 2006). Allen \& Meyer (1990) defined organizational commitment as an individual's psychological attachment to an organization, which also refers to the individual's desire to remain in the organization. According to Mowday, et al. (1979) organizational commitment is characterized by the presence of three psychological factors, they are accepting of organizational goals and values, willingness to exert great effort to achieve organizational goals, and a strong desire to remain in the organization. The model proposed by Allen and Meyer states that organizational commitment is experienced by employees as three simultaneous mindsets that include affective, continuance, and normative commitments. Affective commitment is defined as the emotional attachment of employees to identification with the organization and involvement in the organization. Employees who have a continuance commitment will remain in the organization because they have to do so to avoid potential losses if they leave the organization. The normative commitment dimension consists of indicators of individual experience before being in the organization and the experience of socialization while in the organization.

On the other side of the JD-R model, organizational commitment as job resources will suppress the appearance of burnout as strain. According to Meyer and Maltin (in Lapointe, et al., 2011), affective commitment is associated with a strong belief that someone behaves according to one's intrinsic values, which creates a sense of autonomy. The psychological state associated with affective commitment allows individuals to function with minimal energy expenditure and without fear of losing resources, which should reduce the possibility of the emergence of burnout (Lapointe, et al., 2011).

H2: Organizational commitment weakens the influence of work-family conflict to burnout.

\section{Method}

This is an inferential quantitative study. This study aims to determine the moderating role of organizational commitment in the work-family conflict relationship with burnout among employees in five food and beverages 
industries in Kuta, Bali. This research was conducted at five companies that were willing to be studied from 50 companies in the food and beverage sectors in Kuta, Bali which was registered in the Department of Human and Energy Resources of Bali Province with a total of 383 employees. The five companies are PT Bali Food Lestari, PT Kita Makan Enak, PT Mykonos Wilarca International, PT Uang-Uang BBQ and Shabu-Shabu, and Rama Beach Resort and Villas. The sample characteristics are employees both men and women who have worked for more than a year in the company. This study selected subjects using proportionate random sampling, which is random sampling with a proportional composition from each sub-population (Azwar, 2013a: 87). The number of samples used is equal to 196 by using Slovin Formula (Umar in Juliandi \& Manurung, 2014: 59) at the significance level $\alpha=0.05$.

Data were collected through the administration of the three instruments of the research variable, which consist of modification of Work-Family Conflict Instrument by Carlson, et al. (2000), modification of Burnout Instrument by Rusandi (2015), and modification of Organizational Commitment Instrument by Allen \& Meyer (1990). A total of 30 respondents were used in the trial of the research instrument. Based on the results of validity test carried out by the item-total correlation method with the Pearson Product Moment formula, there are several items that have a correlation coefficient $\leq 0.25$ so that they are declared invalid in the research instrument. Invalid items are item number 8 in Burnout Instrument and items number 4, 5, 6, 8, 9, 12, 17, 18, and 24 in Organizational Commitment Instrument. Whereas all items in the Work-Family Conflict Instrument are declared valid because they have a correlation coefficient above 0.25 . Respondents' answers to invalid items in the questionnaire were not included in the data analysis.

Table 1. Validity Test Results

\begin{tabular}{|l|l|l|}
\hline Variable & Number of Items & Coefficient of Correlation \\
\hline Burnout & $1,2,3,4,5,6,7,9,10,11$, & $0.550 ; 0.419 ; 0.461 ; 0.572 ; 0.285 ; 0.580 ; 0.542 ; 0.449 ;$ \\
& 12, & $0.671 ; 0.487 ; 0.694$ \\
\hline Organizational & $1,2,3,7,10,11,13,14,15$, & $0.561 ; 0.379 ; 0.646 ; 0.667 ; 0.253 ; 0.373 ; 0.496 ; 0.601 ;$ \\
Commitment & $16,19,20,21,22,23,24$ & $0.386 ; 0.562 ; 0.747 ; 0.597 ; 0.359 ; 0.580 ; 0.629$ \\
\hline Work-family conflict & $1,2,3,4,5,6,7,8,9,10,11$, & $0.666 ; 0.758 ; 0.675 ; 0.618 ; 0.640 ; 0.732 ; 0.757 ; 0.740 ;$ \\
& $12,13,14,15,16,17,18$ & $0.695 ; 0.666 ; 0.727 ; 0.655 ; 0.663 ; 0.712 ; 0.683 ; 0.781 ;$ \\
& & $0.810 ; 0.360$
\end{tabular}

Instrument reliability test was carried out by a single trial administration method using Alpha coefficient formula (Azwar, 2013b: 115). The reliability test results show Burnout Instrument reliability coefficient of 0.725 , Organizational Commitment Instrument of 0.805, and Work-Family Conflict Instrument of 0.934. All research instruments were declared reliable because they had Cronbach Alpha coefficients above 0.6.

Table 2. Reliability Test Results

\begin{tabular}{|c|c|c|}
\hline Variable & Cronbach Alpha Coefficient & Item Total \\
\hline Burnout & 0.725 & 11 \\
\hline Organizational Commitment & 0.805 & 15 \\
\hline Work-family conflict & 0.934 & 18 \\
\hline
\end{tabular}

\section{Results}

The characteristics of the respondents were described based on the demographic data listed in the questionnaire, which are the name of the company, the period of employment, gender, age, and status. The respondents were divided proportionally into five companies. They are PT Bali Food Lestari with the percentage of respondents amounting to $58.7 \%$, PT Kita Makan Enak with the percentage of respondents amounting to 12.2\%, PT Mykonos Wilarca International with the percentage of respondents amounting to 7.7\%, PT Uang-Uang BBQ \& Shabu Shabu with the percentage of respondents amounting to $12.8 \%$, and Rama Beach Resort \& Villas with a percentage of respondents amounting to $8.7 \%$.

Based on the working period, the research respondents were divided into three groups, namely the research respondents with a work period of less than two years with the percentage of respondents amounting to $32.7 \%$, research respondents with a working period of two to five years with the percentage of respondents amounting to $44.9 \%$ and research respondents with a work period of more than five years with a percentage of respondents of $22.4 \%$.

Sex demographic data shows that there are more male respondents than female respondents with a percentage of $61.2 \%$ for men and $38.8 \%$ for women. Based on age, the respondents of the study were categorized as adolescents, which were less than 26 years old had the highest percentage of respondents at $58.2 \%$. While the research respondents aged 26 to 45 years old who are adults have a percentage of respondents of $39.3 \%$, and respondents who are over 45 years old have a percentage of respondents of $2.5 \%$. Based on demographic status data, the research respondents who were unmarried had a greater percentage than respondents who were married, with the percentage of unmarried respondents amounting to $60.2 \%$ and those who were married at $39.8 \%$. 
The results of the descriptive analysis of the research variables indicate that the average value of respondents' answers to burnout is 2.59 which is included in the low category, organizational commitment is 3.25 which is included in the sufficient category, and work-family conflict is 2.81 which is included in the sufficient category.

The assumption test results show that the data are normally distributed $(\alpha=0.364)$, there is no heteroscedasticity in the regression model $(\alpha 1=0.402 ; \alpha 2=0.347 ; \alpha 3=0.062)$, and there is no multicollinearity between independent variables in this study $($ Toll1 $=0.898 ;$ VIF1 $=1.114$; Toll $=0.961$; VIF2 $=1.040$; Toll3 = 0.923 ; VIF3 = 1.083).

Table 3. Normality Test Results

\begin{tabular}{|c|c|}
\hline & Unstandardized Residual \\
\hline Asymp. Sig. (2-tailed) & 0.364 \\
\hline
\end{tabular}

Table 4. Heteroscedasticity Test Results

\begin{tabular}{|c|c|}
\hline Variable & Sig. \\
\hline ZX & 0.402 \\
\hline ZXm & 0.347 \\
\hline ZX-ZXm & 0.062 \\
\hline
\end{tabular}

Table 5. Multicollinearity Test Results

\begin{tabular}{|c|c|c|}
\hline Variable & Tollerance & VIF \\
\hline ZX & 0.898 & 1.114 \\
\hline ZXm & 0.961 & 1.040 \\
\hline ZX-ZXm & 0.923 & 1.083 \\
\hline
\end{tabular}

The results of the hypothesis test indicate that the independent variables in this study simultaneously significantly influence the dependent variable $(\alpha=0.00)$. The coefficient of determination of 0.262 shows that the burnout variable can be explained through work-family conflict, organizational commitment, and the interaction between work-family conflict and organizational commitment of $26.2 \%$, while the remaining $73.8 \%$ is explained by other variables outside this study.

Table 6. F Test Results

\begin{tabular}{|l|l|l|l|l|l|}
\hline Model & Sum of Squares & Df & Mean Square & F & Sig. \\
\hline Regression & 1378.686 & 3 & 459.562 & 22.681 & 0.000 \\
\hline Residual & 3890.314 & 192 & 20.262 & & \\
\hline Total & 5269.000 & 195 & & & \\
\hline
\end{tabular}

Table 7. Coefficient of Determination Results

\begin{tabular}{|c|c|c|}
\hline $\mathrm{R}$ & R Square & Adjusted R Square \\
\hline 0.512 & 0.262 & 0.250 \\
\hline
\end{tabular}

The significance value of $\beta 1<0.05$ and positive $\beta 1$ values indicate that work-family conflict positively influence burnout. The value of $\beta 1$ is 2.391 indicating that when work-family conflict increases by one unit, burnout will increase by 2.391 units. Through these findings, $\mathrm{H} 1$ is acceptable.

The significance value of $\beta 3<0.05$ indicates that organizational commitment significantly moderates the influence of work-family conflict to burnout. The significance value of $\beta 2<0.05$ indicates that organizational commitment significantly influence burnout. Negative $\beta 3$ values indicate that organizational commitment as a moderator variable weakens the influence of work-family conflict to burnout. The $\beta 3$ value of -0.876 shows that when the interaction between work-family conflict and organizational commitment increases by one unit, burnout will decrease by 0.876 units.

Significant $\beta 2$ and $\beta 3$ values indicate that the type of moderator variable in this study is quasi-moderator. The $\beta 2$ value of -0.700 shows that when organizational commitment increases by one unit, burnout will decrease by 0.700 units. Through these findings, $\mathrm{H} 2$ can be accepted.

Table 8. t Test Results

\begin{tabular}{|c|c|c|c|c|c|}
\hline \multirow{2}{*}{ Model } & \multicolumn{2}{|c|}{ Unstandardized Coefficients } & Standardized Coefficients & \multirow{2}{*}{ Sig. } \\
\cline { 2 - 5 } & B & Std. Error & Beta & & \\
\hline (Constant) & 29.373 & 0.522 & & 56.232 & 0.000 \\
\hline ZX & 2.391 & 0.340 & 0.460 & 7.028 & 0.000 \\
\hline ZXm & -0.700 & 0.329 & -0.135 & -2.130 & 0.034 \\
\hline ZX-ZXm & -0.876 & 0.413 & -0.137 & -2.121 & 0.035 \\
\hline
\end{tabular}

\section{Discussion}

The results showed that work-family conflict positive and significantly affected burnout. This shows that the higher 
work-family conflict, the higher the burnout experienced by employees. Previous research that supports the results of this study were Wright, et al. (2014), Reichl, et al. (2014) and Asiedu, et al. (2018). This finding is in accordance with the JD-R model which states that burnout as a strain arises when work-family conflict as job demand exceeds job resources. This shows that it is important for companies to create a flexible work environment so as to minimize the occurrence of work-family conflict as job demand. The lower the work-family conflict, the lower the chance of burnout.

The results also showed that organizational commitment weakened the influence of work-family conflict on burnout. This finding is in accordance with the JD-R model which states that organizational commitment as job resources will suppress the appearance of burnout as a strain. Individuals who experience work-family conflict can avoid the appearance of burnout when they have high organizational commitment. This is in line with previous studies which stated that organizational commitment moderates the influence of work-family conflict to burnout (Galletta, et al., 2019)

Significant $\beta 2$ and $\beta 3$ values indicate that the organizational commitment variable is a quasi-moderator. Quasi moderator is a variable that moderates the relationship between the independent variables on the dependent variable which at the same time becomes an independent variable (Utama, 2016). In addition to moderating the effect of work-family conflict on burnout, organizational commitment also affects burnout significantly. This finding is in accordance with previous studies which stated that organizational commitment has a negative effect on burnout (Enginyurt, et al., 2016).

\section{Conclusion}

Based on the results and discussion, it can be concluded that work-family conflict positively influences burnout, and organizational commitment significantly weakens the influence of work-family conflict to burnout in food and beverages industries employees in Kuta, Bali. This means that the higher work-family conflict, the higher the burnout experienced by employees. Individuals who experience work-family conflict can avoid the appearance of burnout when they have organizational commitment.

\section{Future Scope}

The results of this study are empirical evidence that can contribute to management science, especially human resource management regarding the influence of work-family conflict on burnout which moderated organizational commitment. The results of this study can produce practical implications that can be developed by companies to reduce the emergence of burnout on employees. Work-family conflict is a predictor of burnout, so it is important for companies to create a flexible work environment to minimize the clash of work interests and family interests. Organizational commitment that is able to weaken the influence of work-family conflicts on burnout must also be a concern for the company. Companies can design training to increase the psychological attachment of employees to companies that are closely related to affective commitment, as well as increasing company value that is closely related to normative commitment.

This study has several limitations that can be taken into consideration in conducting further research. The scope of research is limited only in Kuta so that research results cannot be generalized to research subjects in different places. In addition, the variables studied in predicting burnout only work-family conflict and organizational commitment, so that other factors that can predict burnout are not examined in this study. This research is also a cross-sectional study so that it can explain phenomena only at a certain time.

\section{References}

Adam, S., Gyorffy, Z., \& Susanszky, E. (2008). Physician burnout in Hungary: A potential role for work-family conflict. Journal of Health Psychology, 13 (7), 847-856.

Ahola, K., Toppinen-Tanner, S., \& Johanna. (2017). Interventions to alleviate burnout symptoms and to support the return to work among employees with burnout: systematic review and meta-analysis. Burnout Research, $4,1-11$.

Allen, N. J., \& Meyer, J. P. (1990). The measurement and antecedents of affective, continuance and normative commitment to the organization. Journal of Occupational and Organizational Psychology, 63 (1), 1-18.

Allen, N. J., \& Meyer, J. P. (1993). Organizational commitment: Evidence of career stage effects. Journal of Business Research, 26 (1), 49-61.

Asiedu, E. E., Annor, F., Amponsah-Tawiah, K., \& Dartey-Baah, K. (2018). Juggling family and professional caring: Role demands, work-family conflict, and burnout among registered nurses in Ghana. Nursing Open, 5 (4), 611-620.

Azwar, S. (2013). Metode Penelitian. Yogyakarta: Pustaka Pelajar.

Azwar, S. (2013). Penyusunan Skala Psikologi. Yogyakarta: Pustaka Pelajar.

Bali, B. P. (2018, May 04). Banyaknya Restoran dan Rumah Makan Dirinci Menurut Kabupaten/Kota di Bali, 2012-2017. Retrieved from Badan Pusat Statistik Provinsi Bali: 
https://bali.bps.go.id/statictable/2018/04/13/87/banyaknya-restoran-dan-rumah-makan-dirinci-menurutkabupaten-kota-di-bali-2012-2017.html

Carlson, D. S., Kacmar, K. M., \& Williams, L. J. (2000). Construction and initial validation of a multidimensional measure of work-family conflict. Journal of Vocational Behavior, 56 (2), 249-276.

Chen, L., Liu, J., Yang, H., Ma, H., Wang, H., Huang, Y., Cheng, H., Tang, D., Liu, M., Luo, H., Qu, H., Shen, D., \& Zhang, N. (2018). Work-family conflict and job burn-out among Chinese doctors: the mediating role of coping styles. BMJ Journal, 31 (1), 1-7.

Cordes, C. L., \& Dougherty, T. W. (1993). A review and an integration of research on job burnout. The Academy of Management Review, 18 (4), 621-656.

Demerouti, E., Bakker, A. B., Nachreiner, F., \& Schaufeli, W. B. (2001). The job demands-resources model of burnout. Journal of Applied Psychology, 86 (3), 499-512.

Enginyurt, O., Cankaya, S., Aksay, K., Tunc, T., Koc, B., Bas, O., \& Ozer, E. (2016). Relationship between organizational commitment and burnout syndrome: A canonical correlation approach. Australian Health Review, 40; 181-187.

Galletta, M., Portoghese, I., Melis, P., Gonzalez, C. I., Finco, G., D'Aloja, E., Contu, P., \& Campagna, M. (2019). The role of collective affective commitment in the relationship between work-family conflict and emotional exhaustion among nurses: a multilevel modeling approach. BMC Nursing, 18 (5), 1-9.

Greenhaus, J. H., \& Beutell, N. J. (1985). Sources of conflict between work and family roles. Academy of Management Review, 10 (1), 76-88.

Hall, D. T., Schneider, B., \& Nygren, H. T. (1970). Personal factors in organizational identification. Administrative Science Quarterly, 15 (2), 176-190.

Hill, A. P., \& Curran, T. (2015). Multidimensional perfectionism and burnout: A meta-analysis. Personality and Social Psychology Review, 20 (3), 269-288.

Jaros, S. (2007). Meyer and Allen model of organizational commitment: Measurement issues. The Icfai Journal of Organizational Behavior, 6 (4), 1-25.

Juliandi, I. A., \& Manurung, S. (2014). Metodologi Penelitian Bisnis, Konsep dan Aplikasi. Medan: UMSU PRESS.

Karim, N. H., \& Noor, N. H. (2006). Evaluating the psychometric properties of Allen and Meyer's organizational commitment scale: A cross-cultural application among Malaysian academic librarians. Malaysian Journal of Library \& Information Science, 11 (1), 89-101.

Lapointe, É., Vandenberghe, C., \& Panaccio, A. (2011). Organizational commitment, organization-based selfesteem, emotional exhaustion and turnover: A conservation of resources perspective. Human Relations, 64 (12), 1609-1631.

Lee, S.-H., Park, J.-Y., Lee, K.-M., Shin, E.-H., Park, J.-M., Nam, H.-A., \& Noh, S.-B. (2016). The convergence effects of commitment of organization and positive psychological capital in nurse on burnout. The Society of Digital Policy and Management, 14 (6), 335-345.

Lingard, H., \& Francis, V. (2006). Does a supportive work environment moderate the relationship between workfamily conflict and burnout among construction professionals? Construction Management and Economics, 24 (2), 185-196.

Lu, A. C., \& Gursoy, D. (2013). Impact of job burnout on satisfaction and turnover intention: Do generational difference matter? Journal of Hospitality \& Tourism Research, 40 (2), 1-26.

Maslach, C., \& Leiter, M. P. (2016). Burnout. In Stress: Concepts, Cognition, Emotion, and Behavior: Handbook in Stress Series, 1 (pp. 351-357). Amsterdam: Elsevier Inc.

Mowday, R. T., Steers, R. M., \& Porter, L. W. (1979). The measurement of organizational commitment. Journal of Vocational Behavior, 14 (2), 224-247.

Nilsen, W., Skipstein, A., \& Demerouti, E. (2016). Adverse trajectories of mental health problems predict subsequent burnout and work-family conflict - a longitudinal study of employed women with children followed over 18 years. BMC Psychiatry, 1-10.

Pu, J., Hou, H., Ma, R., \& Sang, J. (2016). The effect of psychological capital between work-family conflict and job burnout in Chinese university teachers: Testing for mediation and moderation. Journal of Health Psychology, 22 (14), 1-9.

Reichl, C., Leiter, M., \& Spinath, F. (2014). Work-nonwork conflict and burnout: A meta-analysis. Human Relations, 67 (8), 979-1005.

Rusandi, M. S. D. 2015. "Hubungan Kecerdasan Emosional terhadap Burnout dengan Komunikasi Organisasi sebagai Moderator pada Perawat Rumah Sakit X". Undergraduate Thesis. Denpasar: Udayana University.

Smith, T. D., Hughes, K., DeJoy, D. M., \& Dyal, M.-A. (2018). Assessment of relationships between work stress, work-family conflict, burnout and firefighter safety behavior outcomes. Safety Science, 103, 287-292.

Utama, M. S. (2016). Aplikasi Analisis Kuantitatif. Denpasar: CV. Sastra Utama.

Wijaya, K. (2015). Masa depan pariwisata bali (Perspektif permasalahan dan solusinya). Jurnal Riset Ekonomi dan Manajemen, 15 (1), 118-135. 
Westman, M., Etzion, D., \& Gattenio, E. (2008). International business travels and the work-family interface: A longitudinal study. Journal of Occupational and Organizational Psychology, 81 (3), 459-480.

Wu, T.-J., Yuan, K.-S., Yen, D. C. \& Xu, T. (2019). Building up resources in the relationship between workfamily conflict and burnout among firefighters: moderators of guanxi and emotion regulation strategies. European Journal of Work and Organizational Psychology, 28 (3), 1-12.

Wright, K. B., Abendschein, B., Wombacher, K., O'Connor, M., Hoffman, M., Dempsey, M., Krull, C., Dewes, A., \& Shelton, A. (2014). Work-related communication technology use outside of regular work hours and work life conflict: The influence of communication technologies on perceived work life conflict, burnout, job satisfaction, and turnover intentions. Management Communication Quarterly, 28 (4), 507-530.

Yu, X., Wang, P., Zhai, X., Dai, H., \& Yang, Q. (2015). The effect of work stress on job burnout among teachers: The mediating role of self-efficacy. Social Indicatiors Research, 122 (3), 701-708. 